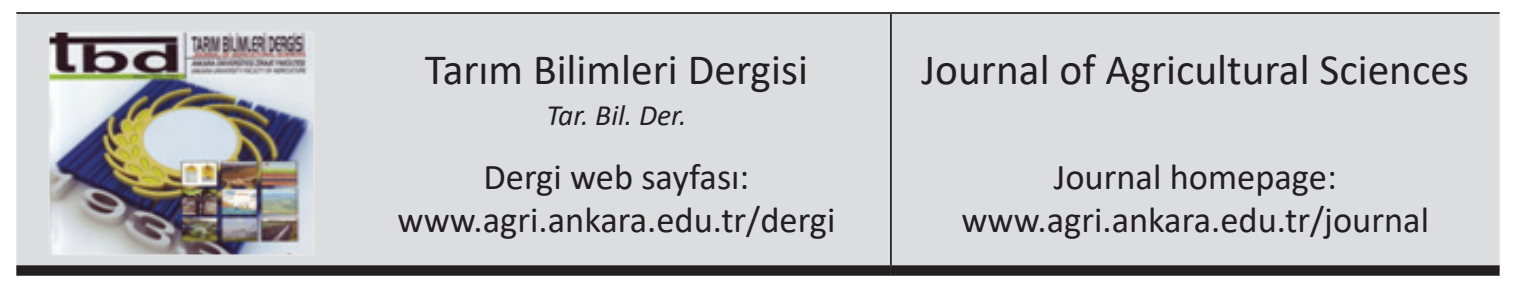

\title{
Effects of Chiral 3-Dichloroacetyl Oxazolidine on Glutathione S-Transferase and Antioxidant Enzymes Activity in Maize Treated with Acetochlor
}

\author{
Fei YE ${ }^{a}$, Hai-Feng CAO ${ }^{a}$, Xue-Song CHEN ${ }^{a}$, Meng ZHANG ${ }^{\text {a }}$, Ying FU ${ }^{\mathrm{a}}$, Chun-Yan $\mathbf{L I}^{\mathrm{b}}$, Shuang GAO \\ ${ }^{a}$ Northeast Agricultural University, College of Science, Harbin, 150030, P.R. CHINA

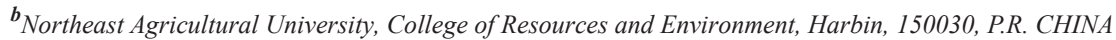

\section{ARTICLE INFO}

Research Article

DOI: 10.15832 /ankutbd.456671

Corresponding Author: Shuang GAO; E-mail: gaoshuang@neau.edu.cn, Tel: +86 (451) 55191507

Received: 08 August 2017, Received in Revised Form: 09 October 2017, Accepted: 24 October 2017

\begin{abstract}
The objective of this paper was to investigate the protective effect of three potential herbicide safeners (3-dichloroacetyl oxazolidine and its two optical isomers) on detoxifying to chloroacetanilide herbicide acetochlor in maize. In this study, physiological and biochemical tests were conducted under laboratory condition in 2015. All safeners increased the expression levels of herbicide detoxifying enzymes, including glutathione S-transferases (GST), catalase (CAT) and peroxidase (POD) to reduce chloroacetanilide herbicide phytotoxicity in maize seedlings. Our results suggest that the R-isomer of R-29148 can induce glutathione (GSH) expression, GST activity, and affinity for the 1-chloro2,4-dinitrobenzene (CDNB) substrate in maize, which can protect maize from injury by chloroacetanilide herbicide acetochlor. Further information on the chiral safener role in antioxidative enzymes activation was obtained from CAT and POD activity to overcome oxidative stress caused by the herbicide.
\end{abstract}

Keywords: Herbicide safener; Chiral 3-dichloroacetyl oxazolidine; Biological activity; GST activity; Acetochlor

(C) Ankara Üniversitesi Ziraat Fakültesi

\section{Introduction}

Acetochlor is a kind of selective herbicide before sprout. It is principally used for control of most annual grasses and certain broadleaf weed species of corn, cotton, cabbage, citrus, and peanut crops. Acetochlor is absorbed mainly by germinating plant shoots, and secondly by roots. It appears to inhibit geranylgeranyl pyrophosphate (GGPP) cyclisation enzyme synthesis in susceptible plants (Braswell et al 2016). However, studies showed that crops injury from acetochlor was greater in wet soil conditions within a two week period after application (Bouchonnet et al 2011; Hausman et al 2013). Corn injury from acetochlor was often associated with the phenomenon that leaves couldn't pull free from the whorl and form a "ladder" like plant. General symptoms included stunted plants with abnormally thick, short roots or twisted shoots and dark green leaves, also (Jursik et al 2011; Braswell et al 2016).

Herbicide safener was a widely used agrochemical with the unique ability to selectively protect crop plants from herbicide damage and 
improve the selectivity of herbicide (Elmore et al 2016). Herbicide safeners are particularly effective in protecting monocot crops by increasing herbicide detoxification (Mhlanga \& Chauhan 2016; Bartucca et al 2017). The current studies suggested herbicide safener appeared to induce a set of enzymes and improve herbicide metabolism (Stoilkova \& Yonova 2010; Buono \& Ioli 2011). It was found that the ability of safeners to protect maize from herbicide damage was related to the induction of glutathione-s-transferase activity $(\mathrm{Fu}$ et al 2011; Li et al 2017). Moreover, the researches had suggested that the detoxification ability of safener was involved in the level of glutathione conjugation in plant (Jo et al 2011; Ye et al 2016). However, the effects of chloroacetanilide safeners on the herbicide detoxification pathway were rarely reported. Safeners naphtbalic anhydride and dichlormid could increase crop tolerance to herbicide acetochlor by increasing the content of GSH and enhancing the activity of GST (Kraehmer et al 2014). It was also found that dichloromethyldioxolane safener protected maize by enhancing the activity of GST on catalyze glutathione conjugation in the metabolic detoxification of chloroacetanilide herbicide acetochlor (Rezaei et al 2013).

Studies indicated that some 3-dichloroacetylsubstituted oxazolidines with a chiral center often have different biological activities (Sriharsha \& Shashikanth 2006; Zhao et al 2015). One of the most widely used dichloroacetamide safeners in maize was 3-(dichloroacetyl)-2,2,5-trimethyl-1,3-oxazolidine (R-29148). It could protect corn effectively by enhancing the expression of GST enzymes, which involved in herbicide detoxification ( $\mathrm{Li}$ et al 2017). The activity of several antioxidative system enzymes, such as CAT and POD, was responsible for alleviating the oxidative stress generated by herbicides (Martins et al 2011; Rajasekar et al 2015; Sytykiewicz 2015). However, there is no clear mechanism for explaining the principle of action of the chiral safeners (Jablonkai 2013). Chiral R-29148 and 3-dichloroacetyl substituted oxazolidines were successfully synthesized in our previous research (Gao et al 2012). Therefore, this study was concerned with the possible mechanism of one chiral centers safeners to alleviate toxicity of acetochlor to maize. Enzyme activities of GSH, GST, POD, and CAT in maize, which treated with safener racemic R-29148 and its chiral isomers, were investigated. It was hypothesized that three potential herbicide safeners could effectively protect maize against herbicide injury.

\section{Material and Methods}

The experiments were carried out with maize seeds Dongnong 253 (Zea mays L.). Racemic R-29148, $\mathrm{R}$-isomer, and S-isomer were synthesized in our laboratory, and their purity levels were greater than $99.0 \%$ (Table 1). Acetochlor emulsifiabale concentrate $(50 \%)$ was provided by Zhongshi Pharmaceutical Co., Ltd (Shandong, China). Acetolachlor standards were purchased from Aladdin Reagent Co., Ltd. And 5,5'-dithiobis(2-nitrobenzoic) acid (DTNB), 1-chloro-2,4dinitrobenzene (CDNB) and GSH were purchased from Sigma (Shanghai, China). Methanol (99.9\%) was provided by Dikma (Beijing, China).

Table 1- Chemical name of safeners

\begin{tabular}{ll}
\hline Safener & Chemical name \\
\hline R-29148 & $\begin{array}{l}\text { 3-(dichloroacetyl)-2,2,5-trimethyl-1,3- } \\
\text { oxazolidine } \\
\text { R-isomer }\end{array}$ \\
& $\begin{array}{l}\text { (R)-3-(dichloroacetyl)-2,2,5-trimethyl- } \\
\text { S-isomer }\end{array}$ \\
& $\begin{array}{l}\text { (S)-3-(dichloroacetyl)-2,2,5-trimethyl- } \\
\text { 1,3-oxazolidine }\end{array}$ \\
\hline
\end{tabular}

Safeners were applied as a seed coating, and maize seeds were soaked in safener solution $(0$, $\left.1,5,10,25,50,100 \mathrm{mg} \mathrm{L}^{-1}\right)$ for $12 \mathrm{~h}$ at $26.5{ }^{\circ} \mathrm{C}$ before sowing. The non-treated control seeds were immersed in distilled water under the same conditions. After soaking, the seeds were germinated at $26.5{ }^{\circ} \mathrm{C}$ for $24 \mathrm{~h}$ in a growth chamber with a $12 / 12$ photoperiod. Next, the seeds were directly sown in paper-cups $(8 \mathrm{~cm} \times 12 \mathrm{~cm})$ containing $150 \mathrm{~mL}$ quartz sand prewashed with $10 \%\left(\mathrm{v} \mathrm{v}^{-1}\right)$ hydrochloric acid solution and sterilized in 5\% 
$\left(\mathrm{w} \mathrm{v}^{-1}\right)$ sodium hypochlorite solution, 6 seeds per cup. The treatments were performed by adding 60 $\mathrm{mL}$ of acetochlor solution $\left(10 \mathrm{mg} \mathrm{L}^{-1}\right)$ to the sand quartz, each cup with water holding capacity at $60 \%$. The control was treated with water. Seedlings were grown at $26.5^{\circ} \mathrm{C}$ under a $12 \mathrm{~h}$ photoperiod using artificial light (relative humidity $75 \%$ ). Plant material was harvested $8 \mathrm{~d}$ after the treatment began. For completely randomized designs, each treatment was replicated thrice. After the treatments, maize shoots and roots were collected and rinsed with water, and then dried through blotting. We determined the shoot and root length as well as fresh weight $(\mathrm{FW})$. The maize growth index recovery rates were calculated to determine the optimal safener concentration. The growth index recovery rates were calculated by Equation (1).
In addition, the shoots and roots were frozen in liquid nitrogen and stored at $-80{ }^{\circ} \mathrm{C}$ for enzymatic assays (GSH, GST, POD, and CAT). The experiment was carried out with three replicates.

GSH level assay: GSH level was measured in accordance with Ismaiel \& Papenbrock (2014). The maize tissue was homogenized in $5 \%\left(\mathrm{w} \mathrm{v}^{-1}\right)$ sulfosalicyclic acid and the homogenates were centrifuged at $15000 \times \mathrm{g}$ for $20 \mathrm{~min}$ at $4{ }^{\circ} \mathrm{C}$. GSH levels in maize roots and shoots were measured using spectrophotometry at $412 \mathrm{~nm}$ with the DTNB reagent and calculated through a comparison with the known concentration.

GST enzyme extraction and assay in vivo: The extraction and assay of GST was performed as described by Buono \& Ioli (2011). To measure the

Recovery rate $(\%)=\frac{\text { Treated with compounds and acetochlor - Treated with acetochlor }}{\text { Contrast - Treated with acetochlor }}$

GST activity, $200 \mathrm{mg}$ frozen maize seedling tissue was ground into powder under liquid nitrogen and homogenized in $1 \mathrm{~mL}$ of QB buffer (potassium

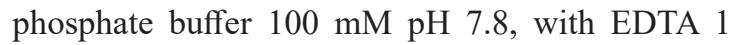
$\mathrm{mM}$ and polyvinylpyrrolidone at $5 \% \mathrm{w} \mathrm{v}^{-1}$ ) at $4{ }^{\circ} \mathrm{C}$. The homogenate was centrifuged at $15000 \times \mathrm{g}$ for $20 \mathrm{~min}$ at $4{ }^{\circ} \mathrm{C}$. The final assay mixture consisted of $50 \mathrm{mM}$ phosphate buffer ( $\mathrm{pH}$ 6.5), $1 \mathrm{mM} \mathrm{CDNB}, 1$ $\mathrm{mM}$ GSH, and $0.5 \mathrm{mM}$ EDTA. The reaction began by adding the root extract. The reaction mixture was measured through spectrophotometry at $340 \mathrm{~nm}$ for $180 \mathrm{~s}$ (60 s intervals). GST activity was expressed as the quantity of herbicide consumed by GSH catalyzed by GST per unit time per mg of enzyme (nmol s $\mathrm{mg}^{-1}$ protein).

GST activity assay in vitro: To determine the GST activity in vitro against acetochlor in this study, HPLC assays were performed to determine the GST activity towards the herbicide acetochlor as substrate in accordance with Scarponi et al (2006). The GST enzyme extraction was added to GSH and an acetochlor standard solution. The reaction mixture was incubated for $2 \mathrm{~h}$. The reaction was stopped by adding $10 \mu \mathrm{L} 3.6 \mathrm{M} \mathrm{HCl}$, and the mixture was extracted with methanol and injected into an HPLC. The GST activity was measured by comparing the initial and residual concentrations of acetochlor. GST activity was expressed as the quantity of acetochlor consumed per minute per milligram of enzyme ( $\mathrm{nmol} \mathrm{min} \mathrm{mg}^{-1} \mathrm{mg}^{-1}$ protein).

Kinetic parameters of GST assay: The kinetic parameters constants $V_{\max }$ and $K_{\mathrm{M}}$ were determined using a linear regression analysis of $1 / V$ vs. $1 / S$ according to double reciprocal plots (Scarponi et al 2006). The GST activity was determined over a range of 1-chloro-2,4-dinitrobenzene (CDNB) concentration (1.0-32.0 mM) at a single GSH concentration of $5 \mathrm{mM}$.

POD enzyme extraction and assay: To investigate the effect of safener to target enzyme, POD activity was determined as described a modified method from Rajasekar et al (2015) with certain modifications. The final assay mixture consisted of $1 \mathrm{~mL} 50 \mathrm{mM}$ sodium phosphate buffer 
(pH 7.0), $2 \mathrm{~mL} 0.3 \%$ of hydrogen peroxide and $0.95 \mathrm{~mL} 0.2 \%$ guaiacol. The reaction was started by addition of $0.01 \mathrm{~mL}$ enzyme extract to reaction mixtures. Then, the POD enzymatic activity was measured through spectrophotometry at $470 \mathrm{~nm}$ for $5 \mathrm{~min}$. The peroxidase activity was expressed as mmol $\mathrm{min}^{-1} \mathrm{~g}^{-1} \mathrm{FW}$.

CAT enzyme extraction and assay: CAT enzymatic activity was determined following the procedures described in Hemanth Kumar et al (2016). The reaction mixtures $\left(1.9 \mathrm{~mL} \mathrm{H}_{2} \mathrm{O}, 0.1\right.$ mL enzyme extract and $1 \mathrm{~mL} 0.3 \%\left(\mathrm{v} \mathrm{v}^{-1}\right)$ hydrogen peroxide) were measured by spectrophotometry at $240 \mathrm{~nm}$ through monitoring the decrease in $\mathrm{H}_{2} \mathrm{O}_{2}$ for $3 \mathrm{~min}$. The catalase activity was expressed as $\mu \mathrm{mol}$ $\mathrm{H}_{2} \mathrm{O}_{2} \min ^{-1} \mathrm{~g}^{-1} \mathrm{FW}$.

The data were analyzed using SPSS version 16.0 software. The least significant difference was applied to assess differences between the treatments using the grouped mean and Duncan multiple range test at a $95 \%$ confidence level $(\mathrm{P}<0.05)$. Data were expressed as mean \pm standard deviation $(\mathrm{n}=3)$.

\section{Results and Discussion}

\subsection{Growth index of maize}

In inhibited growth experiments of the maize, the acetochlor showed a severe shoot and root growth retardation. The treated maize growth index inhibition rate based on the plant height, fresh weight of shoot, root length, and root fresh weight decreased by $42,27,36$ and $24 \%$, respectively. To determine a suitable treatment regime, a range of concentrations of safeners were tested for their ability to decrease the injury caused by acetochlor. The protective effects of three safeners at different concentrations were recorded for R-29148 at the concentration 25 $\mathrm{mg} \mathrm{L}^{-1}, \mathrm{R}$-isomer at the concentration $5 \mathrm{mg} \mathrm{L}^{-1}$, and S-isomer at the concentration $50 \mathrm{mg} \mathrm{L}^{-1}$. The results showed that all the three safeners significantly decreased the inhibition by the acetochlor herbicide, and the order of protective ability of three chiral safeners was as follows: R-isomer > R-29148 > $\mathrm{S}$-isomer. The maize growth indicator recovery rates ranged from 54 to $139 \%$ as shown in Figure 1 , respectively.
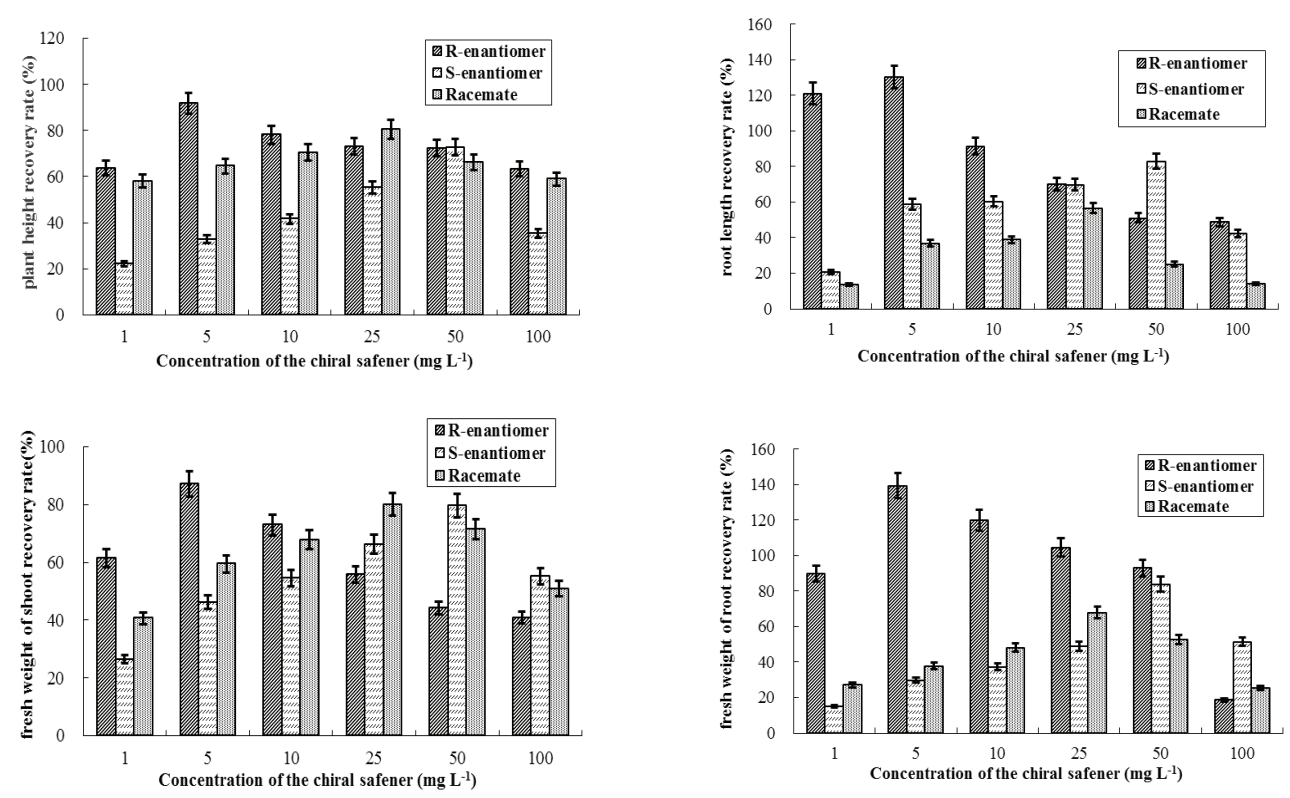

Figure 1- Recovery rate of growth indexes of maize affected by acetochlor and safeners 


\subsection{GSH level}

In the maize root and shoot tissue, increases of GSH level after pretreatment with safeners were greater than with the acetochlor treatment (Table 2). Similarly, GSH level in the seedling tissue with the R-isomer-acetochlor treatment was greater than with the acetochlor treatment in maize. After pretreatment with the R-enantiomer the GSH contents markedly increased by 86 and $53 \%$ in the root and shoot respectively. Our results suggested that the enhanced GSH level in the maize seedlings may be related to the protective activity of herbicide safener.

Table 2- Effect of safeners and acetochlor on GSH level

\begin{tabular}{lcc}
\hline Treatment & $\begin{array}{c}\text { GSH level in } \\
\text { root } \\
\left(\mu g g^{-1}\right)\end{array}$ & $\begin{array}{c}\text { GSH level in } \\
\text { shoot } \\
\left(\mu g g^{-1}\right)\end{array}$ \\
\hline Control & $4.043 \pm 0.331 \mathrm{~d}$ & $10.044 \pm 0.171 \mathrm{~d}$ \\
Acetochlor & $4.391 \pm 0.282 \mathrm{~d}$ & $12.354 \pm 0.234 \mathrm{c}$ \\
R-isomer+Acetochlor & $8.192 \pm 0.149 \mathrm{a}$ & $18.868 \pm 0.178 \mathrm{a}$ \\
S-isomer+Acetochlor & $5.446 \pm 0.473 \mathrm{~b}$ & $10.068 \pm 0.429 \mathrm{~d}$ \\
R-29148+Acetochlor & $4.810 \pm 0.356 \mathrm{c}$ & $15.519 \pm 0.322 \mathrm{~b}$ \\
\hline
\end{tabular}

\subsection{GST activity}

The GST activity in vivo of maize seedling root treated by racemic R-29148 or R-isomer combined with acetochlor showed significantly increases (Table 3). The data indicated that the safener could enhance the GST activity, and the enhanced GST activity facilitated maize seedling survival at low acetochlor concentrations. When acetochlor was added as the substrate instead of CDNB, as expected, the in vitro activity of GST was also enhanced due to the chiral safeners (Table 3). The results of GST activity in maize indicated that different protect effects of safener in the maize root were due to the different levels of GST enzyme activity toward CDNB or acetochlor substrate. The R-isomer effectively promoted the GST activity among the three safeners.

\subsection{Kinetic parameters of GST}

The kinetic parameters tests of maize GST were carried out by using enzymatic extracts from maize roots (Table 4). The $V_{\max }$ of this process decreased, while the $K_{\mathrm{M}}$ increased under treatment with acetochlor. $V_{\max }$ increased by 60 and $18 \%$ after treated by R-isomer and racemic R-29148 compared with the untreated control, and the $K_{\mathrm{M}}$ decreased by 24 and $7 \%$, respectively. The results in Table 4 showed that obvious influence of R-enantiomer to induction and dynamics of GST activity.

Table 4- Effect of safeners and acetochlor to kinetic parameters of GST

\begin{tabular}{lcc}
\hline Treatment & $\begin{array}{c}V_{\max } \\
\left(\text { nmol } \text { min }^{-1} \mathrm{mg}^{-1} \text { protein }\right)\end{array}$ & $\begin{array}{c}K_{m} \\
\left(\mathrm{mmol} \mathrm{L}^{-1}\right)\end{array}$ \\
\hline Control & $14.87 \pm 0.030 \mathrm{c}$ & $0.51 \pm 0.042 \mathrm{~b}$ \\
Acetochlor & $6.69 \pm 0.044 \mathrm{e}$ & $0.56 \pm 0.027 \mathrm{a}$ \\
R-isomer & $23.82 \pm 0.023 \mathrm{a}$ & $0.39 \pm 0.019 \mathrm{~d}$ \\
S-isomer & $12.73 \pm 0.067 \mathrm{~d}$ & $0.50 \pm 0.043 \mathrm{~b}$ \\
R-29148 & $17.54 \pm 0.035 \mathrm{~b}$ & $0.48 \pm 0.037 \mathrm{c}$ \\
\hline
\end{tabular}

\subsection{POD and CAT activity}

The activities of POD and CAT were involved in metabolizing the oxidative stress due to high herbicide doses and protecting plants from the stress generated by herbicide. The effect of

Table 3- Effect of safeners and acetochlor on GST

\begin{tabular}{llll}
\hline Treatment & $\begin{array}{l}\text { GST activity in vivo } \\
\left.\text { (nmol s } \mathrm{mg}^{-1} \text { protein }\right)\end{array}$ & Treatment & $\begin{array}{l}\text { GST activity in vitro } \\
\left.\text { (nmol } \text { min }^{-1} \mathrm{mg}^{-1} \text { protein }\right)\end{array}$ \\
\hline Control & $7.67 \pm 0.32 \mathrm{~d}$ & Control & $68.17 \pm 2.65 \mathrm{c}$ \\
Acetochlor & $8.39 \pm 0.44 \mathrm{c}$ & Acetochlor & - \\
R-isomer+Acetochlor & $20.68 \pm 0.65 \mathrm{a}$ & R-isomer & $117.88 \pm 5.11 \mathrm{a}$ \\
S-isomer+Acetochlor & $8.17 \pm 0.38 \mathrm{c}$ & S-isomer & $34.60 \pm 2.39 \mathrm{~d}$ \\
R-29148+Acetochlor & $11.68 \pm 0.49 \mathrm{~b}$ & R-29148 & $99.05 \pm 4.07 \mathrm{~b}$ \\
\hline
\end{tabular}


safeners and acetochlor on POD and CAT activity were determined to investigate the protective effectiveness of chiral safeners (Table 5). Compared with the control, POD activity in the maize seedling roots exhibited a significant increase. In addition, an extreme decrease in POD activity was observed after treatment with the S-isomer and racemic R-29148 compared with the acetochlor treatment alone. Upon treatment with the R-isomer, POD enzyme activity decreased from 2388 to 1834 .

CAT was involved in metabolizing the oxidative stress due to high herbicide doses and then protecting plants from the stress generated by herbicide. In this case, CAT activity increased to 9.00 after the acetochlor treatment compared with the untreated control. The data in Table 5 showed that the CAT activity decreased to $7.60,2.30$ and 4.60 after treatment with three safeners, respectively.

Table 5- Effect of safeners and acetochlor on CAT and POD activity

\begin{tabular}{lcc}
\hline Treatment & $\begin{array}{c}\text { CAT Activity } \\
\left(\mu \mathrm{mol} \mathrm{min}^{-1} \mathrm{~g}^{-1}\right. \\
F W)\end{array}$ & $\begin{array}{c}\text { POD Activity } \\
\left(\text { mmol min }^{-1} \mathrm{~g}^{-1}\right. \\
F W)\end{array}$ \\
\hline Control & $2.09 \pm 0.03 \mathrm{~d}$ & $1135 \pm 3.25 \mathrm{e}$ \\
Acetochlor & $9.00 \pm 0.05 \mathrm{a}$ & $2388 \pm 4.87 \mathrm{~b}$ \\
R-isomer+Acetochlor & $7.60 \pm 0.03 \mathrm{~b}$ & $1834 \pm 1.62 \mathrm{~d}$ \\
S-isomer+Acetochlor & $2.30 \pm 0.01 \mathrm{~d}$ & $1988 \pm 2.21 \mathrm{c}$ \\
R-29148+Acetochlor & $2.09 \pm 0.03 \mathrm{~d}$ & $1135 \pm 3.25 \mathrm{e}$ \\
\hline
\end{tabular}

Marked acceleration of glutathione conjugation responsible for herbicide resistance in plant had been well-documented (Ismaiel \& Papenbrock 2014). Safeners can stimulate GST activity and effectively detoxify by enzyme-catalyzed conjugation of GSH with the acetochlor herbicide (Scarponi et al 2006; Jablonkai 2013). This meant that the detoxification ability of safener could be decided by the degree of glutathione conjugation in maize to a certain extent. Overall, the R-isomer could protect maize from chloroacetanilide herbicide injury with enhanced GSH content and stimulated GST activity to promote glutathione conjugation with acetochlor in the maize seedlings. Compared with treated by acetochlor, dynamics of GST activity toward CDNB in safener- treatment increased significantly (Ye et al 2016). The data showed that the R-isomer significantly altered the kinetic parameter $V_{\max }$ and $K_{\mathrm{M}}$.

Reports show that POD and CAT were involved in herbicide tolerance and two antioxidant enzymes activity increase during herbicide exposure (Rajasekar et al 2015; Sytykiewicz 2015). Our results further suggested that the activities of POD and CAT in maize were decreased by treated with the R-isomer, which indicates resistance to oxidative stress in which the chiral safener played a certain role in maize. This mechanism could be an important pathway for chiral safener detoxification in maize.

\section{Conclusions}

Based on data obtained in this study, it can be concluded that the effects of racemic R-29148 and its chiral isomers on growth and enzymes activity of maize could protect maize against injury from chloroacetanilide herbicides acetochlor. We investigated the changes of GST, CAT and POD activity after treatment with a safener. The maize growth level and GST activity were significantly inhibited by acetochlor, which could be tempered by adding the R-isomer. The results also suggested that the R-isomer can affect POD and CAT activity, which detoxified the plant from the effects of the acetochlor. Moreover, further studies are still needed to determine the exact mechanism of chiral safener to protect maize from injury by chloroacetanilide herbicide.

\section{Acknowledgements}

This research was funded by the National Nature Science Foundation of China (31572042), the Natural Science Foundation of Heilongjiang Province (ZD2017002, C2015013), Heilongjiang Province Postdoctoral Science Foundation (LBH-Z16030), the National Students' Innovation and Entrepreneurship Training Program (201710224002), Heilongjiang Province Students' Innovation and Entrepreneurship Training Program (201710224002), and the Research Science 
Foundation in Technology Innovation of Harbin (2017RAQXJ017).

\section{References}

Bartucca M L, Celletti S, Astolfi S, Mimmo T, Cesco S, Panfili I \& Buono D D (2017). Effect of three safeners on sulfur assimilation and iron deficiency response in barley (Hordeum vulgare) plants. Pest Management Science 73: 240-245

Bouchonnet S, Kinani S, Souissi Y, Bourcier S, Sablier M, Roche P, Boireau V \& Ingrand V (2011). Investigation of the dissociation pathways of metolachlor, acetochlor and alachlor under electron ionizationapplication to the identification of ozonation products. Rapid Communications in Mass Spectrometry 25: 93103

Braswell L R, Cahoon C W, York A C, Jordan D L \& Seagroves R W (2016). Fluridone and encapsulated acetochlor reduce protoporphyrinogen oxidase inhibitor use in a glufosinate-based palmer Amaranth Management Program for Cotton. Weed Technology 30: $838-847$

Buono D D \& Ioli G (2011). Glutathione S-Transferases of Italian Ryegrass (Lolium multiflorum): Activity toward some chemicals, safener modulation and persistence of atrazine and fluorodifen in the shoots. Pesticide Biochemistry and Physiology 59: 13241329

Elmore M T, Brosnan J T, Armel G R, Vargas J J \& Breeden G K (2016). Herbicide Safeners increase creeping Bentgrass (Agrostis stolonifera) tolerance to Pinoxaden and affect weed control. Weed Technology 30: $919-928$

Fu Y, Yang M W, Ye F \& Gao S (2011). Glutathione S-transferase, acetolactate synthase and safener: a study to reduce herbicidal pollution. The $5^{\text {th }}$ International Conference on Bioinformatics and Biomedical Engineering, 10-12 May, Wuhan, China, pp. 707-709

Gao S, Fu Y, Zhao L X, Xing Z Y \& Ye F (2012). Synthesis of novel chiral N-dichloroacetyl-2-substituented-5methyl-1,3-oxazolidines. Heterocycles 85: 903-910

Hausman N E, Tranel P J, Riechers D E, Maxwell D J, Gonzini L C \& Hager A G (2013). Responses of an HPPD Inhibitor-Resistant Waterhemp (Amaranthus tuberculatus) Population to Soil-Residual Herbicides. Weed Technology 27: 704-711
Hemanth Kumar N K, Meena S K, Meena V S \& Shobha $\mathrm{J}$ (2016). Oxidative stress and antioxidant metabolic enzymes response of maize (Zea Mays L.) seedlings to a biotic stress (Alachlor) condition. International Journal of Agriculture and Crop Sciences 8: 22272231

Ismaiel A A \& Papenbrock J (2014). The effects of patulin from Penicillium vulpinum on seedling growth, root tip ultrastructure and glutathione content of maize. European Journal of Plant Pathology 139: 497-509

Jablonkai I (2013). Herbicide safeners: effective tools to improve herbicide selectivity. Retrieved in December 17, 2014 from http://dx.doi.org/10.5772/55168

Jo H J, Lee J J \& Kong K H (2011). A plant-specific tau class glutathione S-transferase from Oryza sativa with very high activity against 1-chloro-2,4dinitrobenzene and chloroacetanilide herbicides. Pesticide Biochemistry and Physiology 101: 265-269

Jursik M, Soukup J, Holec J \& Andr J (2011). Herbicide mode of actions and symptoms of plant injury by herbicides: Inhibitors of very long chain fatty acid biosynthesis. Listy Cukrovarnicke A Reparske 127: 15-19

Kraehmer H, Laber B, Rosinger C \& Schulz A (2014). Herbicides as weed control agents: State of the Art: I. Weed control research and Safener technology: The path to modern agriculture. Plant Physiology 166: 1119-1131

Li D Z, Xu L, Pang S, Liu Z Q, Wang K \& Wang C J (2017). Variable levels of glutathione S-transferases are responsible for the differential tolerance to metolachlor between maize (Zea mays) shoots and roots. Journal of Agricultural and Food Chemistry 65: $39-44$

Martins P F, Carvalho G, Gratão P L, Dourado M N, Pileggi M, Araújo W L \& Azevedo R A (2011). Effects of the herbicides acetochlor and metolachlor on antioxidant enzymes in soil bacteria. Process Biochemistry 46: 1186-1195

Mhlanga B, Chauhan B S \& Thierfelder C (2016). Weed management in maize using crop competition: A review. Crop Protection 88: 28-36

Rajasekar M, Rabert G A \& Manivannan P (2015). Triazole induced changes on biochemical and antioxidant metabolism of Zea mays L. (Maize) under drought stress. The Journal of Plant Stress Physiology 1: $35-42$ 
Rezaei M K, Shobbar Z S, Shahbazi M, Abedini R \& Zare S (2013). Glutathione S-transferase (GST) family in barley: Identification of members, enzyme activity, and gene expression pattern. Journal of Plant Physiology 170: 1277-1284

Scarponi L, Quagliarini E \& Buono D D (2006). Induction of wheat and maize glutathione S-transferase by some herbicide safeners and their effect on enzyme activity against butachl or and terbuthylazine. Pest Management Science 62: 927-932

Sriharsha S N \& Shashikanth S (2006). Synthesis and antimicrobial activity of novel 1, 3-oxazolidine nucleoside analogs. Heterocyclic Communications 12: $213-218$
Stoilkova G \& Yonova P (2010). Safeners for chlorsulfuron onmaize (Zeamays L.). Quality Assurance and Safety of Crops \& Foods 2: 28-35

Sytykiewicz H (2015). Transcriptional responses of catalase genes in maize seedlings exposed to cereal aphids' herbivory. Biochemical Systematics and Ecology 60: 131-142

Ye F, Cao H F, Fu Y, Zhao L X \& Gao S (2016). The safener effect of chiral derivatives of 3-dichloroacetyl oxazolidine against haloxyfop-P-methyl-induced toxicity in maize. Zemdirbyste-Agriculture 103: 29-34

Zhao L X, Qu H T, Fu Y, Gao S \& Ye F (2015). Alleviation of injury from chlorimuron-ethyl in maize treated with safener 3-dichloroacetyl oxazolidine. Canadian Journal of Plant Science 95: 897-903 